\title{
Critical Factors Inhibiting Performance of Small- and Medium-Scale Contractors in Sub-Saharan Region: A Case for Malawi
}

\author{
Paul John Kulemeka, ${ }^{1,2}$ Grant Kululanga, ${ }^{3}$ and Danny Morton ${ }^{2}$ \\ ${ }^{1}$ PJK\&P Consulting Engineers, P.O. Box 2032, Lilongwe, Malawi \\ ${ }^{2}$ Research and Graduate School, University of Bolton, Deane Campus, Deane Road, Bolton BL3 5AB, UK \\ ${ }^{3}$ Department of Civil Engineering, The Malawi Polytechnic, University of Malawi, Private Bag 303, Blantyre 3, Malawi
}

Correspondence should be addressed to Paul John Kulemeka; paulkulemeka@yahoo.com

Received 6 March 2015; Accepted 17 June 2015

Academic Editor: F. Pacheco-Torgal

Copyright (C) 2015 Paul John Kulemeka et al. This is an open access article distributed under the Creative Commons Attribution License, which permits unrestricted use, distribution, and reproduction in any medium, provided the original work is properly cited.

\begin{abstract}
The construction industry is dominated by small- and medium-scale contractors (SMCs) who face an emerging trend of unique challenges in the implementation of projects. The study was aimed at examining inhibiting factors that influence performance of SMCs in terms of "quality of work," "tender estimation," "tender preparation," and "timely completion of construction projects" in Malawi. A survey questionnaire was administered to 370 players in the construction industry which included public sector clients, contractors, consultants, and construction resource trainers in order to elicit data from 118 variables that were identified through a careful literature review. The inhibiting factors were generally dominated by economic issues, which was an emerging trend to what has been previously reported in the sub-Saharan region. The first highest ranked inhibiting factors were high lending interest regimes offered by financial institutions; stringent conditions to access capital; fluctuation of currency; stringent requirements for obtaining bonds; and high taxes. The research lays the foundation for further understanding of inhibitors on performance of SMCs in an evolving world which is being impacted by global factors and punctuated by sudden changes.
\end{abstract}

\section{Introduction and Background}

The definition of a small-scale contractor varies from country to country. A small-scale contractor is defined broadly as one with limited capital investment, who may need financial and managerial support to effectively run his or her business [1]. This description of small-scale contractors suits characteristics of firms classified by the National Construction Industry Council (NCIC) of Malawi as small- and mediumscale contractors [2]. Malawi is one of the countries in southern sub-Saharan Africa. For this study, therefore, smallscale and medium-scale contractors have the same definition. For small-scale (and medium-scale) contractors, creating an enabling environment includes removal of barriers to their entry into the market and to their growth and sustainability [1]. Part of the enabling process may be to offer the small- and medium-scale contractors (SMCs) support, which will facilitate their access to the necessary resources to start and sustain their businesses [3]. Most governments have outsourced to the private sector some of the activities that were previously carried out in-house by government departments. This measure has been adopted by most states in the sub-Saharan region. Due to the absence of suitable small-scale local entrepreneurs in most countries, it has been found necessary to develop and empower small and medium enterprises (SMEs) to participate in contracting [1]. The initiative to support the SMEs has mainly been the direct or indirect responsibility of governments as observed by Thwala and Mvubu [4] in the success stories from countries such as Malaysia and Singapore. The best option for a given country depends on the state of development of the construction industry (consultant/contractor capacities, experience with contracting) [5].

However, very little research has been undertaken in understanding inhibiting factors to performance of SMCs in the sub-Saharan region $[4,6]$. A research study which was undertaken, with some similarities, is about one and a 
half decades ago [7]. Other research studies conducted in the region were aimed at determining solutions to a single contemporary challenge $[8,9]$. Many of the research studies that have been conducted in the sub-Saharan region were not necessarily on SMCs and generally were not specific to construction business areas such as buildings [10-14]. The need to get abreast of the constraints to the delivery of projects cannot, therefore, be overemphasised. Equally, much of the reported research work has come from regions other than the sub-Saharan region and is generally not specifically about SMCs [15-30]. Furthermore, such research has generally listed inhibiting factors to performance without exploring the salient issues or general trends that should lead to systemic solutions $[31,32]$. The foregoing has had a major impact on the development of the construction industry in the sub-Saharan region. For example, practitioners in the region have generally employed measures that have worked elsewhere with the hope that such measures would address the challenges that small-scale contractors face in their states [33]. While at times such measures have worked, in most of the times, the measures have been disastrous. It should be noted that solutions that worked elsewhere did so when the construction business environments of those regions remained static or unchanging for fairly a long time in the distant past. However, such construction business environments are a feature of the past. Today's construction business environment is characterised by dynamic changes punctuated with increasing uncertainties in technology, budgets, and development processes [34]. Such is the current order of the construction business environment. The foregoing only underscores the need to continuously understand the root causes of performance and underperformance more vigilantly and tied to specific periods.

Generally, SMCs seem to focus on quick fixes and such measures most often address symptoms of their performance challenges. The consequences of addressing symptoms have led some construction industries of developing countries into vicious cycles of undesirable level of quality of service and products [35]. It should be pointed out that effective improvement is derived by understanding the root causes to challenges of performance by SMCs operation in a dynamic environment characterised, for instance, by financial shocks, international protocols, insurgency, and so forth. As such, a symptom of underperformance should be a precursor for uncovering its root causes. Thus, the study was aimed at examining the constraints that are important in Malawi with regard to SMCs and any pattern of changes or shifts in inhibiting factors.

The Roads Authority (RA) is a parastatal responsible for the maintenance, rehabilitation, and construction of the public road network in Malawi. The RA engages the largest number of civil consultants and contractors annually with projects across the entire nation. Out of the 1,368 small- to mediumscale contracts outsourced by Roads Authority between 2007/2008 and 2010/2011 financial years (FYs), 1,327 were executed by SMCs. The RA faced challenges in the implementation of its roads programmes as it had to outsource all its works and services to an industry dominated by the SMCs. Section 25 (3) of the Roads Authority Act of 2006 stipulates that RA shall not itself undertake any work for the construction, maintenance, or rehabilitation of any road but enter into contract with any outside contractor for the purpose.

Table 1 shows the outcome of projects carried out by SMCs between 2007/08 and 2010/11 FYs classified into successful, fair, and unsuccessful.

The 1,327 small- and medium-scale contracts executed by SMCs between 2007/08 and 2010/11 financial years were $53.8 \%$ successful, $26.7 \%$ fair, and $19.5 \%$ unsuccessful. Effectively, $46 \%$ of the contracts were completed outside the allowed period or not completed at all.

A desk study of road projects data at Roads Authority showed that outstanding among SMCs' shortfalls were poor quality of work, failure to complete projects on time, and poor tender preparation and estimation.

Poor Quality of Work. Records at RA showed that ex gratia extension of time was granted on projects that could not be handed over due to poor quality. Consequently, additional time had to be allowed for contractors to rework and bring the works to acceptable level for handover and payment certification. The RA did not impose any penalties on these contracts, hence the granting of ex gratia extension of time. Generally, the decision to grant ex gratia extension of time was based on tangible efforts which the contractor was seen to be putting into the project in trying to achieve the required standards and specifications. From Table 1 it can be seen that delivery of approximately $27 \%$ of projects executed by SMCs between 2007/2008 and 2010/2011 FYs was affected by poor quality of work.

Failure to Complete Projects on Time. When, at the end of the contract period, it was obvious that the SMCs could not complete the remaining work, even if ex gratia extension of time was granted, the RA "closed" or "terminated" the contract. If the RA was satisfied with the quality of work completed thus far, no penalties were imposed and the project was "closed." However, if it was clear that the efforts were unimpressive at the end of the contract period, the RA "terminated" the contract and blacklisted the contractor for 12 months. If at the end of the grace period, the ex gratia extension of time, the contract was still not finished, the RA allowed the works to continue but the additional time attracted liquidated damages. Application of liquidated damages did not trigger blacklisting of the contractor. If the SMCs completed the works successfully at the end of the grace period, no penalty was imposed. The foregoing shows that delivery of at least $19 \%$ of projects carried out by SMCs between 2007/2008 and 2010/2011 FYs was either not completed or had liquidated damages clause invoked.

Ironically, there was a poor performance by the SMCs in this period despite the good economic conditions that prevailed between 2007 and 2010 as can be demonstrated by rate of change of real GDP of above $8 \%$ during this period. Figure 1 shows the rate of change of real GDP between 2007 and 2010 which was above $8 \%$.

Poor Tender Preparation (Responsiveness) and Estimation. A study of tender evaluation reports showed that there 
TABLE 1: Performance classification of small- to medium-scale contracts executed between 2007/08 and 2010/11 FYs.

\begin{tabular}{lccc}
\hline Scale & $\begin{array}{c}\text { Successful } \\
\text { Completed ahead of } \\
\text { time or on time }\end{array}$ & $\begin{array}{c}\text { Ex gratia extension of time granted } \\
\text { for project to be completed }\end{array}$ & $\begin{array}{c}\text { Unsuccessful } \\
\text { terminated or closed uncompleted }\end{array}$ \\
\hline Small & 571 & 309 & 205 \\
Medium & 143 & 45 & 54 \\
Total & 714 & 354 & 259 \\
\hline Percentage against total & $53.8 \%$ & $26.7 \%$ & $19.5 \%$ \\
contracts executed by SMCs & & & \\
\hline
\end{tabular}

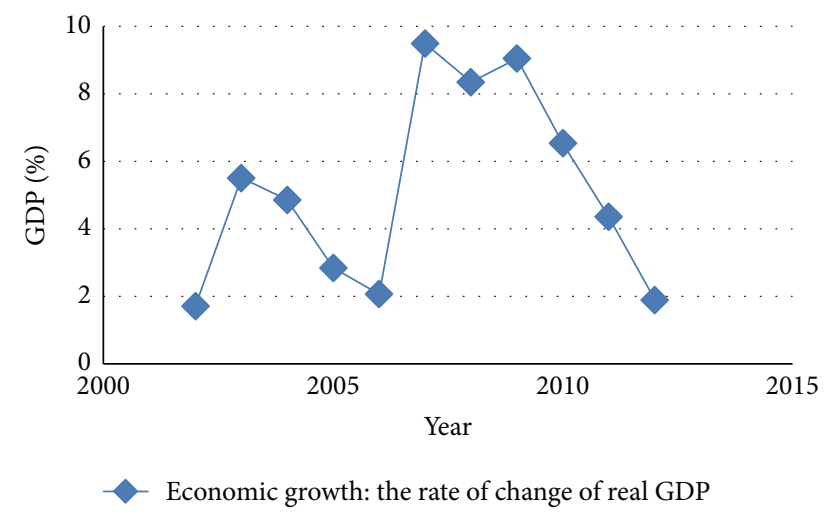

FIGURE 1: Economic growth: the rate of change of real GDP. Source: http://www.indexmundi.com/malawi/gdp_real_growth_rate.html (2309-2014).

TABLE 2: Summary of tender rejection causes for 2006/07 to 2010/11 period.

\begin{tabular}{llc}
\hline & Reason for rejection & Number \\
\hline 1 & Bid security & 145 \\
2 & Annual construction turnover & 1,150 \\
3 & Past experience & 1,286 \\
4 & Plant and equipment & 895 \\
5 & Supervision staff (Site Agent/Foreman) & 1,237 \\
6 & Liquid assets or credit facilities & 1,563 \\
7 & Tender price above or below engineer's & 1,962 \\
\hline
\end{tabular}

Some tenders had more than one reason for rejection.

were seven conditions for which tenders were disqualified or rejected by RA. Table 2 shows tender evaluation results for 887 small- and medium-scale road projects that were advertised during the 5 -year period between 2006/2007 and 2010/2011 FYs. Altogether, 9,382 tenders were received and evaluated and a total of 5,763 tenders were disqualified due to failure to respond to at least one bidding requirement or due to tender prices that fell outside the engineer's estimates bracket.

Reasons for rejection of bids 1 to 6 above are attributes and characteristics which a firm possessed. For any of them to cause rejection of a tender during an evaluation exercise it meant that the bidding firm fell short of the minimum level required for the particular project to be executed successfully. If the rejected firm had the necessary experience and attributes, it may also have meant that the personnel preparing the tender had failed to present the information successfully. In this study tender responsiveness, as a performance indicator, refers to any of the two scenarios or both. Unlike reasons for rejection 1 to 6 , reason 7 varies according to a number of factors ranging from macroeconomic to profit mark-ups and implementation methods and strategies. The study has isolated tender estimation as a stand-alone performance indicator. This is crucial because Table 2 shows that the major cause of tender rejection in the five-year period was due to tender prices being above or below the engineer's estimates.

Therefore, the investigation in this research focused on following commonly reported indicators of performance as well as "quality of work," "tender estimation," "tender responsiveness," and "timely completion" of construction projects. The literature review and interaction with senior members from private and public client organisations, contractors, and consultants yielded 118 factors that were considered constraints in the delivery of projects by SMCs which are summarised in Appendix.

The paper is a report on "work in progress" of a larger study being undertaken arising from need to understand factors inhibiting efficient and effective delivery of public road construction projects by SMCs in Malawi in terms of timely completion, quality of work, tender preparation, and tender estimation. In addition, the study will establish mitigation measures of inhibiting factors to construction project executed by the SMCs.

\section{Literature Review}

In this paper, discussion of performance inhibiting factors on construction projects has centred, mainly, on some of the studies conducted in the sub-Saharan region. Chan and Kumaraswamy [36] compared the results of the research in Hong Kong with researches done in Saudi Arabia and Nigeria and found that the respondents' interpretation of causes and their importance were different. Furthermore, Elhag et al. [37] observed that factors identified in Okpala and Aniekwu's [38] study of causes of high costs of construction in Nigeria were largely influenced by the locality of the country in which the research was conducted. It was noted that underdeveloped economies tend to exert different influences on construction costs compared to developed economies 
such as the UK. Consequently, for purposes of this study, a review of factors involving countries in the sub-Saharan region was considered more relevant than a review of factors from countries from other regions.

\subsection{Changing Measures of Construction Project Performance.} In the early 1990s, project success was considered to be tied to performance measures, which in turn were tied to project objectives [34]. At the project level, success was measured by the project duration, monetary cost, and project performance [39]. Atkinson [40] called the time, cost, and quality criteria the "Iron Triangle." However, he argued that using the Iron Triangle of project management, time, cost, and quality as the criteria of success may have resulted in biased measurement of project management success. He, rather, proposed to shift the focus of measurement for project management from the exclusive process driven criteria to the Square Route, which has four major categories for success criteria: the Iron Triangle, the Information System, Stakeholder Community Benefits, and Organisational Benefits. A significant number of literatures emphasized more the time aspect as an indicator for project success. Both Nkado [41] and Chan and Kumaraswamy [36] quoted NEDO Faster Building for Commerce published in 1988, which regarded completing projects on time as a symbol of an efficient construction industry. The Latham Report [42] suggested that ensuring timely delivery of projects is one of the important needs of clients of the construction industry.

The Project Management Book of Knowledge (PMBOK) Construction Extension [43] recognises 13 project management knowledge areas, namely, project integration management, scope management, time management, cost management, quality management, human resource management, communication management, risk management, procurement management, safety management, environmental management, financial management, and claim management on which success measures ought to be based. Sustainable development concepts, namely, environmental respect, social integration, and social economy, are factors with growing importance as indicators of successful performance of infrastructure projects [44].

2.2. Study Performance Indicators. Measuring the performance of any construction project in terms of success or failure, despite looking simple, is in fact a very complex process [19]. Modern construction projects even moderate in size are generally multidisciplinary in nature and they involve participation of designers, contractors, subcontractors, specialists, construction managers, and consultants. The objectives or goals of all participants need not be the same even in a given project. Hence to define the success or failure of a project without specifying the participant and without specifying the criteria for judging the performance holds no meaning [19]. The present study has identified quality of work, timely completion, tender estimation, and tender preparation as measures of performance.

2.2.1. Quality of Work. In construction projects, quality of work is associated with adherence to conditions of the contract and specifications stipulated in the contract documents in their entirety during the execution of the project. The Concise Oxford English Dictionary defines quality as the standard of something as measured against other things of a similar kind [45]. However, there are two distinct areas in which quality of work achieved is measured for success. The first one is by measuring and testing of construction materials forming the elements of the work product in situ or in the materials laboratory against a standard measure or specification. These materials must fulfill the prescribed characteristics in the contract documents for them to be incorporated into the construction process. Similarly, the work product must be within prescribed standard characteristics to be considered successful. This is generally fulfilled through the testing of the product at different stages during or after each job process. The second aspect of quality of work concerns what beneficiaries see and feel when making use of the construction product. This is a product of workmanship. Workmanship has been defined in the Concise Oxford English Dictionary as the degree of skill with which a product is made or job is done [45]. Some aspects of workmanship are fulfilled automatically when project specifications are adhered to. For example, when the surfacing stone sizes are within tolerance, the road will be nice and smooth to drive on. Similarly, when the final layer of a road base is within the stipulated level tolerance, the road will be comfortable to ride on. However, the degree of riding comfort of a road, all other things being equal, will depend on how the level tolerance has been controlled within the lower and upper limits. The road will be more comfortable to ride on where the upper and lower tolerance limits have been maintained to the minimum than where they have been allowed to fluctuate from the uppermost to the lowermost limits. Consequently, Griffin [46], when describing the organization and management of quality control for small works, combined the phrases "quality of work" and "workmanship." He described quality of work (workmanship) as involving ensuring that the attributes of the work satisfy the specified needs; measuring, where possible, the ongoing and finished works against recognized standards; and implementing, where appropriate, quality control and quality assurance procedures. Quality is meeting the customer requirements [47].

2.2.2. Timely Completion of Construction Projects. Time on construction projects is concerned with

(i) planning of the work over the anticipated duration (programme) in relation to its requirements with full appreciation of the resources needed and resources available; planning for utilization sets the basis or yardstick (plan) against which progress can be monitored and assessed;

(ii) progressing which follows the programming of the work and compares the work undertaken against the plan allowing for the redistribution of resources, if necessary, to speed up the work if it is falling behind the plan [46].

Time overrun is the delay beyond planned completion dates traceable to the contractors [17]. The construction industry 
plays a major role in the development of many countries. At the macro level, delay will lead to a negative rate of national economic growth and monetary loss [26, 48-50]. At the micro level, a delayed project can lead to time and cost overruns, disputes, arbitration, and even total abandonment $[26,51]$. Delays in construction projects are global phenomena and Malawi and the sub-Saharan region are no exception. This trend has become the norm rather than the exception, especially in developing countries [29]. This scenario, thus, constitutes a major risk and debilitating effect on relationships and cash flow among employers, consultants, and contractors, which can lead to exhaustive disputes, arbitrations, and expensive litigations. The significance of this impact, therefore, clearly justifies the concern over such a chronic problem facing the industry.

2.2.3. Tender Preparation. A tender or bid is a formal offer to supply goods or services for an agreed price [52]. Tendering is the process used by many construction clients to obtain the programme and price for building a project [53]. Tendering typically consists of three parts: deciding on the type of contract and the terms and conditions that would form the basis of the contractual relationship and under which the work will be done; selecting the most suitable contractor given the budget and time available; and establishing the contract price [53]. Important elements at tender preparation stage include the following:

(i) Establishment of a realistic contract period on which the tender may be based.

(ii) Identification of construction methods.

(iii) Assessment of method related items which affect the bid price.

(iv) Making provisions to aid the build-up of contract preliminaries and plant expenditures.

(v) Making provisions to aid the tendering/estimating process.

To arrive at the project tender price, the costs arising from elements in (i) to (iv) including overheads and mark-up, compiled by the estimator, have to be adjudicated by senior management or the owner of the organization. The purpose of the adjudication is to assess the risk inherent in the tender and decide upon a competitive bid price [54].

2.2.4. Tender Estimation. For any project, both construction supply chain relationships and implementation strategies are decided at tender stage and do influence the bid preparation and ultimately the contract price. The way construction projects' supply chains are configured may determine their final success or failure [55]. Therefore, if the contract price is correct, both the supply chain and construction project will function efficiently and effectively and the whole project will be a success. The engineer's estimate is, therefore, crucial because it will affect the successful implementation of the supply chain management during the construction project. Only if the engineer's estimate is correct will it be possible to attain the level of service required to produce the right quality of products, at the correct time and budget.
When the number of bidders is large, as is the case in a slow economy, an owner runs a significant risk of selecting a contractor that has either accidentally or deliberately submitted an unrealistically low price [56]. Rogerson [3] reported that central to the success of the programme for target procurement of small, medium, and microenterprises on the N4 road project were the process and rules of tender adjudication where, among other strategies, price was used as a basis upon which the largest number of tender applications was eliminated. Therefore, on the basis of Malawi being a developing country, the question is not whether or not tender price should be used as one of the tender elimination criteria, but rather to find the suitable ways of making sure that the engineer's estimates are correct and relevant for each individual project.

Cost estimation is an experience-based process. Construction practitioners are aware of uncertainty, incompleteness, and unknown circumstances of factors affecting construction costs [37]. Realisation and understanding of cost determinants enrich the competence of cost estimators and hence, along with decent cost forecasting techniques, deliver more reliable and accurate cost estimates. Smaller contractors who often deliver the work packages have to compute their estimates from first principles to be able to furnish accurate quotes to the larger contractors [57]. The need for computing estimates from first principles is necessary for SMCs in developing countries like Malawi according to Cooke and Williams [54] who noted that the use of bidding theories by senior managers in adjudicating tenders is only relevant in a stable market place.

\subsection{Contractors' Performance Constraints and Inhibiting} Factors. Constraint is defined as a constraining condition, agency, or force that limits the systems' performance in a given context/environment [58, 59]. Removing constraints from bottleneck(s) is the most effective means of improving overall system performance $[60,61]$. Once the existing constraints are removed, however, new ones emerge. This calls for continued research in order to establish emerging constraints with a view to reduce or minimize their impact on construction projects and sustain successful performance. The terms "performance constraints" and "performance inhibiting factors" have the same meaning in this study and have been used interchangeably.

Adams [7] identified the following to be constraints on indigenous contractors' performance in Nigeria: uncertainties in supplies and prices of materials, obtaining interim payment, procuring work, access to capital, negotiating variation payment, access to plant and equipment, inappropriate contract conditions, maintaining plant and equipment, resolving contract disputes, meeting contract deadlines, design changes, incomplete contract documents, transporting materials and equipment, materials control on site, providing reliable tenders, communicating with client/representatives, shortages of skilled labour, public image, accounting of financial management, inadequate supervision by client, project planning and site management, technical know-how, commitment to construction, company organization, personnel management, providing quality workmanship, corruption, 
changes in government and economy, prejudice against indigenous contractors' competence, theft and fraud by own employees, double taxation, and breach of contract by public clients.

Other studies carried out in Nigeria revealed the following delay factors: poor contract management, financing and payment of completed works, changes in site conditions, shortages of materials, imported materials and plant items, design changes, subcontractors and nominated suppliers, contractor's financial difficulties, client's cash flow problem, architect's incomplete drawing, subcontractor's slow mobilization, equipment breakdown and maintenance problem, suppliers late delivery of ordered materials, incomplete structural drawings, contractor's planning and scheduling problems, price escalation and subcontractor's financial difficulties, contractors' difficulties in receiving payments from public agencies, inadequate public agencies' budgets, improper payment to contractor for completed work, problems in planning, unrealistic time estimation, frequent changes in material and design, and noncompliance with the contract conditions [62-65].

Fugar and Agyakwah-Baah [14] found the following to be causes of delays in building construction projects in Ghana: delay in honoring payment certificates, underestimation of cost of projects, underestimation of complexity of projects, difficulty in accessing bank credit, poor supervision, underestimation of time for completion by contractors, shortage of materials, poor professional management, fluctuation of prices, poor site management, construction methods, delay in instructions from consultants, late deliveries of materials, lack of programme of works, delay by subcontractors, poor design, breakdown of equipment, client initiated variations, obtaining permit from municipality, insufficient communication between parties, necessary variations, shortage of skilled labour, legal disputes, unfavourable site conditions, foundation conditions encountered on site, discrepancy between design specification and building code, bad weather conditions, mistakes with soil investigations, unskilled equipment operators, accidents during construction, shortage of unskilled labour, and public holidays.

Frimpong et al. [10] studied 26 factors that cause cost overruns in construction of ground water projects in Ghana. According to the contractors and consultants, monthly payments difficulties were the most important cost overruns factor, while owners ranked poor contractor management as the most important factor. Despite some difference in viewpoints among the three groups surveyed, there is a high degree of agreement among them with respect to their ranking of the factors. The overall ranking results indicate that the three groups felt that the major factors that can cause excessive groundwater project cost overruns in developing countries are poor contractor management, monthly payment difficulties, material procurement, poor technical performances, and escalation of material prices.

In their paper "Current Challenges and Problems Facing Small and Medium Size Contractors in Swaziland" Thwala and Mvubu [4] identified the following factors as constraints to the success of SMCs in Swaziland and South Africa: lack of business management skills, lack of financial management skills, exorbitant interest rates from banks, compulsory business management services, risks involved in construction industry, lack of access to finance both during preconstruction and construction, bad relationships with suppliers, late payments of completed work by the client, lack of collateral, bidding for projects beyond contractor technical or financial capacity, lack of skills to properly program projects resources in monthly segments for healthy cash flow, inability to prepare documents for timely payment, misunderstanding of terms of contract, inability to use applicable contractual instruments to demand performance by client, and failure to demand performance of client for fear of being "red listed." Also, in South Africa, there are documented unethical behaviour and corrupt practices, respectively, in the construction industry $[66,67]$. Corruption was found to be occurring at all participation levels and in all phases of construction projects.

In Malawi the following areas were identified to be amongst constraints and challenges faced by small, medium, and microenterprise contractors: training (to teach writing and reading skills, financial management, and business management skills), business management skills (to ensure sustainable business enterprises), financial management (to manage cash flow, among other things), unethical manners (to combat collusion, professional pricing the same job for more than one bidder, among others), and information technology (to make specific software available such as those required to aid preparation of works programmes) [6].

The following were found to be causes of delay in traditional contracts: owner interference, inexperienced contractor, improper payments of completed work, labour productivity, poor site management, slow decision making, construction methods, and improper planning subcontractors [18].

\section{Methodology}

The research used the quantitative approach since the study was aimed at establishing which of the 118 factors were important and impacting the reported performance indicators in Malawi with regard to SMCs. In addition the study was also aimed at identifying any pattern or shifts in inhibiting factors. Questionnaire survey was adopted owing to its suitability for descriptive and explanatory research and the large number of questions and anticipated sample size [68]. Although this method of data collection suffers from poor response rate it, nonetheless, allows views from a wide range of credible participants to be obtained $[69,70]$.

In order to provide for comparative analysis of the results with previous studies, the questionnaire was structured in the same fashion as the one in the study by Adams [7] in Nigeria. The questions were grouped into three categories as follows: constraints emanating from the environment, constraints emanating from clients or client representatives (consultants), and constraints emanating from contractors' deficiencies. The classification scheme presented by Adams [7] corresponds with that of Odeh and Battaineh [18] which is a categorization of factors representative of players in a 
traditional form of contract. The constraints causing challenges in the delivery of construction projects by SMCs have been arranged under the following 3 major groups: (i) external-related factors, (ii) client/client representative(consultant-) related factors, and (iii) contractor-related factors [18].

The same questionnaire was administered to the contractors, clients, and consultants. The questionnaire was designed in such a way that it had three parts. The first part contained four broad questions. The first question assessed the opinion of the respondents on how much they considered the identified factors to be constraints for the SMCs in Malawi. The second question asked the respondents to indicate how much they considered the factors affected performance of SMCs in general. The third question asked respondents how much they considered the factors to impact the performance indicators on projects executed by SMCs. Lastly, the fourth question asked respondents how much they considered the four performance indicators, namely, quality of work, timely completion, tenders estimation, and tender responsiveness, to be issue on projects carried out by SMCs. The second and third parts of the questionnaire contained questions aimed at establishing the characteristics and attributes of the respondents' firms and the respondents themselves, respectively.

3.1. Sample Size and Selection. The research employed quota, purposive, and convenience sampling in selecting cases since only one questionnaire was administered to each contractor. The sampling quotas were based on proportional numbers of contractors in three operating business categories (civil, building, and civil and building combined), proportioned to the three contractors' scales (small, medium, and large), and further proportioned to the three regions of Malawi. The sampling was purposive because only owners or senior personnel were targeted respondents. Convenience sampling was adopted because priority was to survey contractors that could be easily located using contact details provided by the NCIC. The sample size was based on a population of indigenous contractors in Malawi, including those in the categories of large-scale contractors. This was due to the fact that almost all indigenous contractors who were in the large-scale NCIC registration categories during the survey were only promoted to those grades within the previous 6 years. Consequently, these contractors were deemed to possess valuable information regarding SMCs.

Sample size determination was based on a framework for deriving minimum required sample size for a given population size of continuous and categorical data developed by Bartlett et al. [71]. The sample size for contractors was found to be a minimum of 296 , for categorical data at $5 \%$ margin of error, against a population of 1,044 contractors. There were 62 consultants registered by NCIC [72] practicing in the fields of engineering, architecture, and quantity surveying. The entire number of consultants was being targeted for the survey since there were less than 100 [73]. Similarly, all the 15 or so public client organisations and training institutions were surveyed, targeting officials from all the three regions of the country and in the various professions of the built environment.

\section{Data Collection and Analysis}

The elicitation of data was on a 1-to-5-point Likert scale (where 1 represented "strongly disagree or least important" and 5 represented "strongly agree and very important") to each of the 118 variables as elements for operations of Malawian SMCs (see Appendix). A similar 5-point Likert scale (where 1 represented "strongly disagree or very important" and 5 represented "strongly agree or least important") was employed in eliciting views on variables of performance (quality of work, tender estimation, tender preparation or responsiveness, and timely completion of projects) for work delivered by SMCs in Malawi. The targeted respondents in all cases were either the owners of the firms or their most senior members of staff, selected because of their "helicopter view" of the companies and the construction industry generally. In order to avoid the poor response rate associated with questionnaire survey, a method of administering questionnaires described by Saunders et al. [68] as "delivery and collection questionnaires" was employed. Questionnaires were administered by hand by enumerators, mostly unemployed graduates, who were given a list of physical addresses of the targeted contractors, consultants, or client organisations. The questionnaires had a covering letter which introduced the enumerator and the purpose of the survey. The enumerators were advised to give the respondents an option of being interviewed or to self-complete the questionnaire, in which case the respondent had to indicate the time for the enumerator to come back to collect a completed questionnaire. Where the targeted respondents declined to participate in the survey or their offices could not be found, a substitute firm with similar characteristics was identified and approached. This exercise went on for 30 days in order to capture as many respondents as possible in the various predetermined quotas and categories in all the three regions of Malawi. The data gathered through questionnaires was analysed and presented using descriptive and inferential statistics. Primary data was logged into Microsoft Excel spreadsheet and later pasted into Statistical Package for Social Sciences (SPSS) Version 20. Data was processed using both Microsoft Excel and SPSS. Three hundred and seventy (370) questionnaires were distributed of which 310 were returned. In order to compare the ranking of the perceptions across more than two groups of respondents, the ranked mean scores were subjected to the Kruskal-Wallis test, a nonparametric test. If the test was significant then a difference existed between at least two of the samples. Similarly, comparison of two groups of independent samples was undertaken by subjecting them to Mann-Whitney test, a nonparametric test that looks for differences between two independent samples [74].

\section{Research Findings and Results}

The response was made up of 235 contractors, 41 clients (from 11 organisations), and 34 consultants, representing 79\%, 73\%, and $55 \%$ of expected returns from contractors, clients, and consultants, respectively.

Up to 95 factors out of 118 were found to be important, in the range of $3.5<x \geq 4$.5. Clarke [75] observed that 
attempting to manage all identified success factors simultaneously and giving them all equal attention is virtually impossible. However, by adopting the Pareto rule of separating out the "important few from the trivial many" to focus attention on the key factors, success is more likely [75]. Therefore, the study only considered the first 24 highest ranked constraints, rather than the 95 , in respect to Pareto's principle. The Pareto principle (also known as the $80-20$ rule) states that, for many events, roughly $80 \%$ of the effects come from $20 \%$ of the causes [76]. In the same vein, this study considered the first 24 variables ranked by major players in the construction industry (clients, consultants, and contractors) collectively and individually to be factors requiring most attention with respect to the SMCs in Malawi. The major players in the construction industry have crucial roles to play in the Malawian construction industry which follows the traditional form of contract of design-bid-build in general and the public sector in particular.

In a study of perceptions of constraints affecting indigenous contractors in Nigeria, Adams [7] noted that the views of experts in the industry, that is, construction professionals (architects, engineers, and quantity surveyors), were more objective than the contractors. Hence, there was a need to segregate information obtained from the groups in order to identify the most appropriate contractors' needs. Since some of the variables were common of the first 24 across one or two or all the individual players, the total number of the combined variables was 45 and is presented in Table 3.

All variables in Table 3 were rated in the range of $3.5<$ $x \leq 4.5$ which was position 4 , "agree." Only one constraint, "inadequate budget allocations," was related to clients or client representatives, 23 constraints were due to SMCs' shortfalls or deficiencies, and 17 factors were related to the operating environment. At least 14 variables were related to economic issues, including the first five. 26 variables were significant at $P \leq 0.05$, meaning there was a difference in their ranking by at least one of the two major players according to the Kruskal-Wallis significant test results. Most of the significant variables were the ones related to SMCs' shortfalls or deficiencies.

Table 4 presents the rating frequency of the last 10 variables rated by the major players in the construction industry. Four variables were related to environmental issues, that is, "use of energy efficient plant or equipment," "environmental protection measures," "use of energy efficient materials," and "green specifications." Table 4 shows that the rating frequencies of the four variables by the major players in the construction were relatively very high in position 3 , "uncertain" $(2.5<x \leq 3.5$ range $)$, the highest being "green specification," whose rating frequency was 126 against a total of 310 .

The overall rating of the performance variables shown in Table 5 is such that "quality of work" had been rated in the range of $3.5<x \leq 4.5$, "agree." The other three performance variables, "timely completion," "tender responsiveness," and "tender estimation," had been rated in the "uncertain" range, $2.5<x \leq 3.5$. "Tender estimation" was the least rated. The clients and consultants, on the other hand, separately rated "quality of work," "timely completion," and "tender responsiveness" in the "uncertain" range whereas "tender estimation" was rated in the "disagree" range, that is, $1.5<$ $x \leq 2.5$. This outcome was not surprising because the variable considered by both clients and consultants to be the most important element affecting SMCs was "poorly prepared tenders or estimates." There was statistically different significant rating, $P<0.001$, against all the four performance variables.

Table 6 shows that there was no significant difference in the rating of the variables according to Kruskal-Wallis test result at $P<0.05$ significant level in the way the contractors carrying work in the respective construction business areas had been rated.

There was significant difference in the ranking of three of the four performance variables ranked by contractors in respective regions between at least two regions' contractors as shown in Table 7. The central and southern region contractors had rated all the performance variables in the same way: "agree" for "quality of work" and "timely completion" and "uncertain" for "tender responsiveness" and "tender estimation." There was agreement in the rating of "tender responsiveness" by northern region contractors with the central and southern regions contractors which had been rated "uncertain." The northern region contractors had rated "disagree" on "tender estimation."

Table 8 shows no significant difference in the ranking of the performance variables by both male and female contractors' respondents where Mann-Whitney test significant statistic $Z \leq \pm 2.196$ or $P \leq 0.05$ for $95 \%$ significant level.

\section{Discussion}

The aggregated variables, 45 in total, were considered important elements for SMCs in Malawi by this study. Most of the variables on this list, especially those related to SMCs' shortfall or deficiencies, were significant at $P \leq 0.05$. Since most of the variables related to economic factors, including the first five as shown in Table 9, were beyond the SMCs' control, public sector client organisations should put in place better measures that should cushion the SMCs against the macroeconomic forces compared with what has been the case before.

"Inability to compete with bigger construction companies" (ranked 6th in current study results in Table 10), which was related to "unfair competition (contract price undercutting by bigger contractors)," could be controlled where price was among the criteria for selecting successful bidders. Limiting contractors to only participate in bidding for specific project in the categories that they were registered in may automatically eliminate the possibility of large contractors going for smaller jobs and competing with SMCs.

The results of the current study when compared to the previous study reported by Adams [7] and depicted in Table 10 show that there are seven in the first top ranked ten constraints related to economic issues against three in the previous study. In addition, among other differences, the current study results show no constraints related to clients or client representatives in the first top ten ranked constraints whereas the previous study had two. The two included "obtaining interim payment" and "inappropriate contract conditions." 


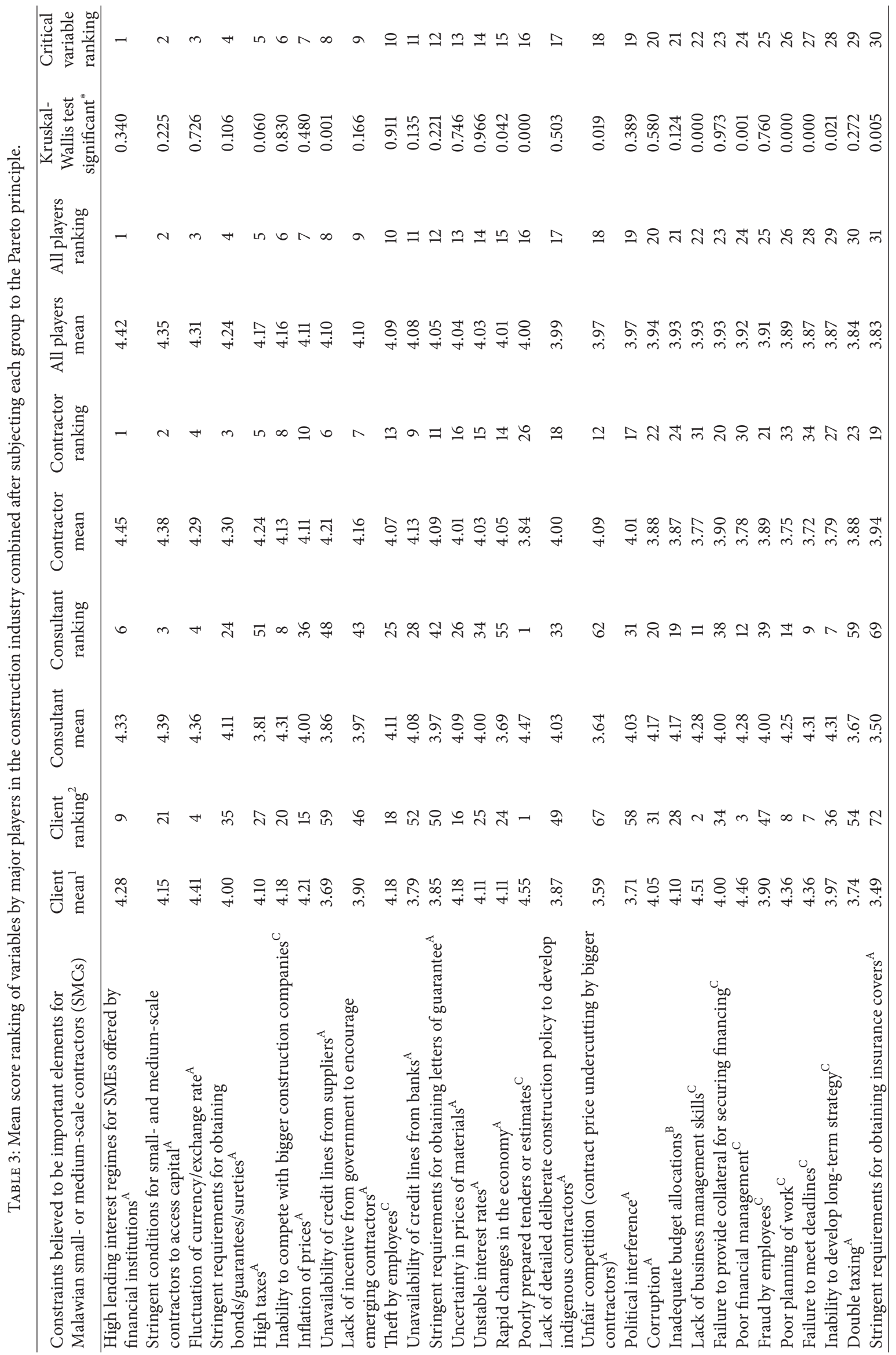




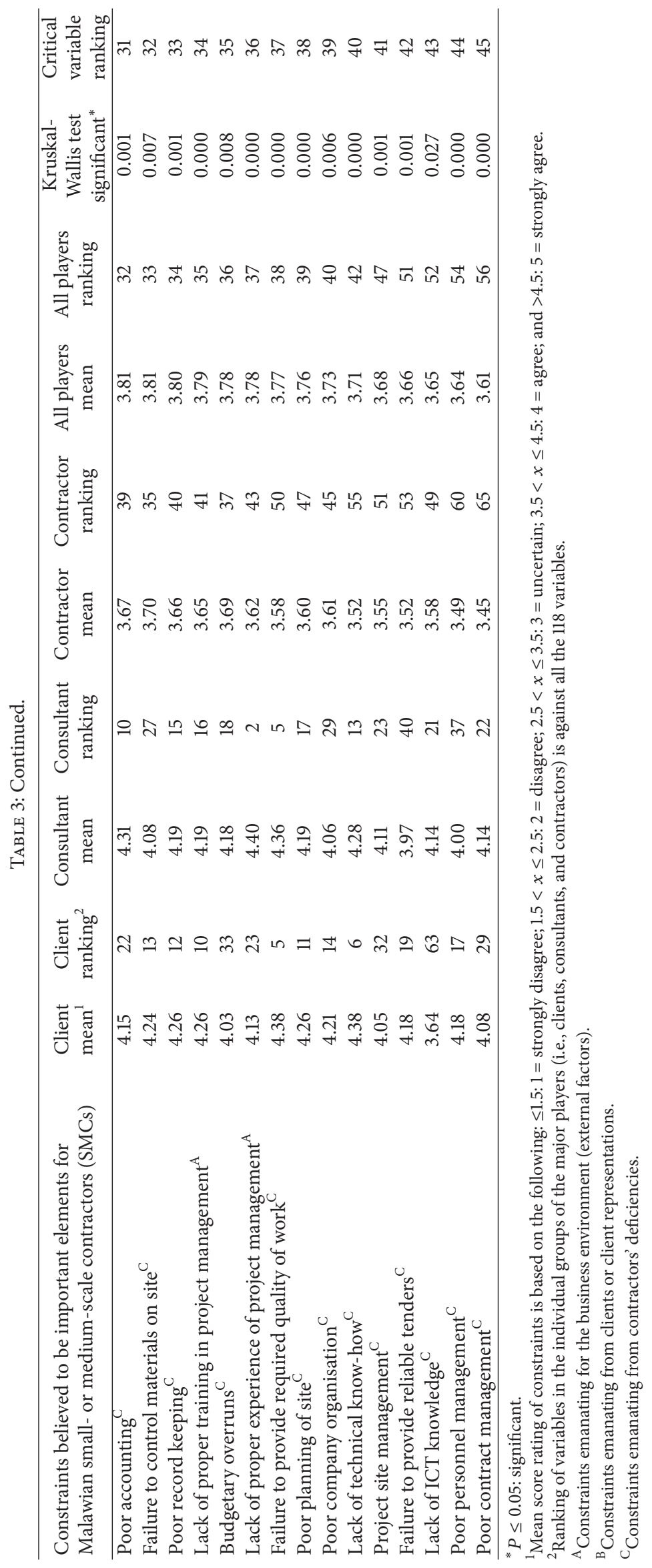


TABLE 4: Rating frequency of the last 10 variables by major players in the construction industry.

\begin{tabular}{|c|c|c|c|c|c|c|c|c|}
\hline $\begin{array}{l}\text { Constraints believed to be important elements for } \\
\text { Malawian small- or medium-scale contractors (SMCs) }\end{array}$ & $\begin{array}{r}\text { Strongly } \\
\text { disagree }\end{array}$ & Disagree & Uncertain & Agree & Strongly agree & Missing & Total & Mean \\
\hline Injuries on site $\mathrm{C}^{\mathrm{C}}$ & 14 & 96 & 58 & 105 & 36 & 1 & 310 & 2.94 \\
\hline Use of energy efficient plant or equipment ${ }^{\mathrm{A}}$ & 23 & 80 & 112 & 79 & 13 & 3 & 310 & 2.93 \\
\hline Environmental protection measures ${ }^{\mathrm{A}}$ & 34 & 99 & 75 & 75 & 25 & 2 & 310 & 2.86 \\
\hline Unpredictable weather conditions $^{\mathrm{A}}$ & 33 & 109 & 69 & 68 & 31 & 0 & 310 & 2.85 \\
\hline $\begin{array}{l}\text { Green specifications (i.e., specifications of } \\
\text { environmentally friendly materials) }\end{array}$ & 27 & 80 & 126 & 59 & 14 & 4 & 310 & 2.85 \\
\hline Use of energy efficient materials ${ }^{A}$ & 26 & 87 & 114 & 72 & 10 & 1 & 310 & 2.85 \\
\hline e-tendering (i.e., submission of tenders electronically) ${ }^{\mathrm{A}}$ & 45 & 101 & 77 & 55 & 30 & 2 & 310 & 2.75 \\
\hline $\begin{array}{l}\text { Unavailability of vehicles to transport equipment to } \\
\text { site }^{A}\end{array}$ & 44 & 141 & 39 & 60 & 23 & 3 & 310 & 2.60 \\
\hline Complicated registration procedure $^{\mathrm{A}}$ & 53 & 137 & 52 & 41 & 24 & 3 & 310 & 2.50 \\
\hline Unavailability of vehicles to transport materials ${ }^{A}$ & 50 & 151 & 39 & 50 & 16 & 4 & 310 & 2.45 \\
\hline
\end{tabular}

${ }^{\mathrm{A}}$ Constraints emanating for the business environment (external factors).

${ }^{\mathrm{B}}$ Constraints emanating from clients or client representations.

${ }^{\mathrm{C}}$ Constraints emanating from contractors' deficiencies.

TABLE 5: Mean score ranking of performance variables by major players in the construction industry.

\begin{tabular}{lccccccccc}
\hline $\begin{array}{l}\text { Performance } \\
\text { variable }\end{array}$ & $\begin{array}{c}\text { Client } \\
\text { mean }\end{array}$ & $\begin{array}{c}\text { Client } \\
\text { ranking }\end{array}$ & $\begin{array}{c}\text { Consultant } \\
\text { mean }\end{array}$ & $\begin{array}{c}\text { Consultant } \\
\text { ranking }\end{array}$ & $\begin{array}{c}\text { Contractor } \\
\text { mean }\end{array}$ & $\begin{array}{c}\text { Contractor } \\
\text { ranking }\end{array}$ & $\begin{array}{c}\text { All players } \\
\text { mean }\end{array}$ & $\begin{array}{c}\text { All players } \\
\text { ranking }\end{array}$ & $\begin{array}{c}\text { Kruskal-Wallis } \\
\text { test significant }\end{array}$ \\
\hline Quality of work & 3.23 & 1 & 3.31 & 1 & 3.96 & 1 & 3.79 & 1 & 0.000 \\
$\begin{array}{l}\text { Time control } \\
\begin{array}{l}\text { Tender } \\
\text { responsiveness }\end{array}\end{array}$ & 2.64 & 2 & 2.57 & 3 & 3.60 & 2 & 3.36 & 2 & 0.000 \\
$\begin{array}{l}\text { Tender } \\
\text { estimation }\end{array}$ & 2.64 & 3 & 2.77 & 2 & 3.41 & 3 & 3.24 & 3 & 0.000 \\
\hline
\end{tabular}

${ }^{*} P \leq 0.05$ : significant.

TABLE 6: Mean score ranking of performance variables by contractors in respective construction business areas.

\begin{tabular}{|c|c|c|c|c|c|c|c|c|c|}
\hline $\begin{array}{l}\text { Performance } \\
\text { variable }\end{array}$ & $\begin{array}{l}\text { Building } \\
\text { mean }\end{array}$ & $\begin{array}{l}\text { Building } \\
\text { ranking }\end{array}$ & Civil mean & $\begin{array}{c}\text { Civil } \\
\text { ranking }\end{array}$ & $\begin{array}{l}\text { Building \& } \\
\text { civil mean }\end{array}$ & $\begin{array}{c}\text { Building \& } \\
\text { civil } \\
\text { ranking }\end{array}$ & $\begin{array}{l}\text { All players } \\
\text { mean }\end{array}$ & $\begin{array}{l}\text { All players } \\
\text { ranking }\end{array}$ & $\begin{array}{l}\text { Kruskal-Wallis } \\
\text { test significant }\end{array}$ \\
\hline Quality of work & 3.68 & 2 & 4.08 & 1 & 3.90 & 1 & 3.79 & 1 & 0.073 \\
\hline Time control & 3.73 & 1 & 3.67 & 2 & 3.52 & 2 & 3.36 & 2 & 0.392 \\
\hline $\begin{array}{l}\text { Tender } \\
\text { responsiveness }\end{array}$ & 3.18 & 3 & 3.52 & 3 & 3.35 & 3 & 3.24 & 3 & 0.289 \\
\hline $\begin{array}{l}\text { Tender } \\
\text { estimation }\end{array}$ & 3.09 & 4 & 3.08 & 4 & 2.91 & 4 & 2.84 & 4 & 0.596 \\
\hline
\end{tabular}

${ }^{*} P \leq 0.05$ : significant.

TABLE 7: Mean score ranking of performance variables by contractors operating in respective regions.

\begin{tabular}{|c|c|c|c|c|c|c|c|c|c|}
\hline $\begin{array}{l}\text { Performance } \\
\text { variable }\end{array}$ & $\begin{array}{c}\text { Centre } \\
\text { mean }\end{array}$ & $\begin{array}{l}\text { Centre } \\
\text { ranking }\end{array}$ & $\begin{array}{c}\text { North } \\
\text { mean }\end{array}$ & $\begin{array}{c}\text { North } \\
\text { ranking }\end{array}$ & $\begin{array}{l}\text { South } \\
\text { mean }\end{array}$ & $\begin{array}{c}\text { South } \\
\text { ranking }\end{array}$ & $\begin{array}{c}\text { All players } \\
\text { mean }\end{array}$ & $\begin{array}{c}\text { All players } \\
\text { ranking }\end{array}$ & $\begin{array}{l}\text { Kruskal-Wallis } \\
\text { test significant* }\end{array}$ \\
\hline Quality of work & 4.05 & 1 & 3.45 & 1 & 3.99 & 1 & 3.79 & 1 & 0.006 \\
\hline Time control & 3.67 & 2 & 3.28 & 2 & 3.60 & 2 & 3.36 & 2 & 0.262 \\
\hline $\begin{array}{l}\text { Tender } \\
\text { responsiveness }\end{array}$ & 3.50 & 3 & 2.83 & 3 & 3.47 & 3 & 3.24 & 3 & 0.006 \\
\hline $\begin{array}{l}\text { Tender } \\
\text { estimation }\end{array}$ & 3.16 & 4 & 2.17 & 4 & 3.03 & 4 & 2.84 & 4 & 0.000 \\
\hline
\end{tabular}

${ }^{*} P \leq 0.05$ : significant. 
TABLE 8: Mean score ranking of performance variables by contractors' male and female respondents.

\begin{tabular}{lcccccccc}
\hline $\begin{array}{l}\text { Performance } \\
\text { variable }\end{array}$ & Male mean & $\begin{array}{c}\text { Male } \\
\text { ranking }\end{array}$ & $\begin{array}{c}\text { Female } \\
\text { mean }\end{array}$ & $\begin{array}{c}\text { Female } \\
\text { ranking }\end{array}$ & $\begin{array}{c}\text { All players } \\
\text { mean }\end{array}$ & $\begin{array}{c}\text { All players } \\
\text { ranking }\end{array}$ & $\begin{array}{c}Z \\
\text { Mann-Whitney test } \\
\text { significant statistic }^{*}\end{array}$ \\
\hline $\begin{array}{l}\text { Quality of work } \\
\text { Time control }\end{array}$ & 3.97 & 1 & 3.86 & 1 & 3.79 & 1 & -0.288 & 0.773 \\
$\begin{array}{l}\text { Tender } \\
\text { responsiveness }\end{array}$ & 3.60 & 2 & 3.68 & 2 & 3.36 & 2 & -0.595 & 0.552 \\
$\begin{array}{l}\text { Tender } \\
\text { estimation }\end{array}$ & 2.36 & 3 & 3.64 & 3 & 3.24 & 3 & -1.198 & 0.231 \\
\hline
\end{tabular}

${ }^{*} P \leq 0.05$ : significant.

TABLE 9: First five top ranked variables from the combined mean scores of major players in the construction industry selected based on Pareto principle.

\begin{tabular}{|c|c|}
\hline Rank & $\begin{array}{l}\text { Constraints believed to be important elements for } \\
\text { Malawian small- or medium-scale contractors (SMCs) }\end{array}$ \\
\hline 1 & $\begin{array}{l}\text { High lending interest regimes for SMEs offered by } \\
\text { financial institutions }{ }^{A}\end{array}$ \\
\hline 2 & $\begin{array}{l}\text { Stringent conditions for small- and medium-scale } \\
\text { contractors to access capital }{ }^{\mathrm{A}}\end{array}$ \\
\hline 3 & Fluctuation of currency/exchange rate ${ }^{A}$ \\
\hline 4 & $\begin{array}{l}\text { Stringent requirements for obtaining } \\
\text { bonds/guarantees/sureties }{ }^{\mathrm{A}}\end{array}$ \\
\hline 5 & High taxes ${ }^{A}$ \\
\hline
\end{tabular}

The relatively high rating frequencies of "uncertain" of the variables related to the environmental issues in Table 4 may be an indication that the construction industry in Malawi was not very familiar with issues of sustainable development. The aim of sustainable development is to improve the quality of life of the present population in a way that will not have a negative impact on future generations [77]. A project is sustainable when it improves in all three sustainable development dimensions, that is, environmental respect, social integration, and social economy, maintaining cost, time, quality, and performance, at an acceptable range [44].

Overall rating, by major players in the construction industry, of performance variables in Table 5 shows that only "quality of work" was rated within "agree" range while the other three, namely, "timely completion," "tender responsiveness," and "tender estimation," were rated "uncertain." This implied that the construction industry in Malawi, with regard to SMCs, was performing at below-average level.

The rating of performance variables by the major players in Table 5 depicted significant difference in the ranking, $P<$ 0.05. Therefore, although the ratings were within the same ranges of "uncertain" and "agree," the significant test results suggested that there was a difference, by at least one of the players, in the way they perceived the performance of SMCs. Similarly, rating of the performance variables by contractors in respective regions yielded significant test results in three of the four variables in Table 7. This implies that at least contractors from one region perceived the impact of the performance variables on SMCs differently to the contractors in one or both of the remaining regions.

There was no significant test result in the rating of performance variables by contractors in respective construction business areas in Table 6 for $P \leq 0.05$. Similarly, there was no significant test result in the rating of performance variables by male and female contractors' respondents in Table 8 for $P \leq 0.05$. Hence, there were no differences in the way contractors in respective construction business areas and male and female contractors' respondents perceived and rated the performance variables.

\section{Conclusions and Recommendations}

The study found that the main inhibitors to performance of small and medium sized contractors were economic in nature. The first $20 \%$ of the variables that were highly rated by the major players in the construction industry constituted 45 as critical elements affecting SMCs in Malawi. Therefore, the small and medium sized contractors will remain unsustainable and their performance unsatisfactory without the intervention of the government. In order to address the challenges faced by the small and medium sized contractors in Malawi, it is critical for the government to continuously review policies with regard to small-scale contractor development programmes to ensure that it contributes to the success of small contractors. The foregoing is in the light of changing circumstances as a result of the dynamism characterising the construction industry. Reliance of measures that have worked in the past may not necessarily be viable today and continued research in this area is crucial as the sector for small-scale operators in the construction industry constitutes the largest proportion of the industry.

The research lays the foundation for further understanding of inhibitors on performance of SMCs in an evolving world which is being impacted by global factors and punctuated by sudden changes. The identification of the underlying factors that specifically undermine performance of SMCs could help stakeholders to reasonably deal with inhibiting factors to performance more accurately and instructively. The inhibiting factors following a financial theme could be utilised to fill the gap of evaluating the performance with empirical method for SMCs. 
TABLE 10: Comparison of previous and current study results of the first 10 top ranked variables.

\begin{tabular}{|c|c|c|}
\hline Rank & Previous study results ${ }^{\dagger}$ & Current study results \\
\hline 1 & Uncertainty in supplies of materials and prices ${ }^{A}$ & $\begin{array}{l}\text { High lending interest regimes for SMEs offered by financial } \\
\text { institutions }{ }^{A}\end{array}$ \\
\hline 2 & Obtaining interim payment ${ }^{\mathrm{B}}$ & $\begin{array}{l}\text { Stringent conditions for small- and medium-scale } \\
\text { contractors to access capital }{ }^{\mathrm{A}}\end{array}$ \\
\hline 3 & $\begin{array}{l}\text { Procuring work: scarcity of openly advertised } \\
\text { tenders }^{\text {A }}\end{array}$ & Fluctuation of currency/exchange rate $\mathrm{A}^{\mathrm{A}}$ \\
\hline 4 & Access to capital $^{\mathrm{A}}$ & $\begin{array}{l}\text { Stringent requirements for obtaining } \\
\text { bonds/guarantees/sureties }{ }^{\mathrm{A}}\end{array}$ \\
\hline 5 & Negotiating variation order ${ }^{\mathrm{A}}$ & High taxes ${ }^{\mathrm{A}}$ \\
\hline 6 & Access to plant and equipment ${ }^{\mathrm{A}}$ & Inability to compete with bigger construction companies ${ }^{\mathrm{C}}$ \\
\hline 7 & Inappropriate contract conditions ${ }^{\mathrm{B}}$ & Inflation of prices ${ }^{\mathrm{A}}$ \\
\hline 8 & Maintaining plant and equipment ${ }^{\mathrm{A}}$ & Unavailability of credit lines from suppliers ${ }^{\mathrm{A}}$ \\
\hline 9 & Failure to resolve contract disputes ${ }^{\mathrm{A}}$ & $\begin{array}{l}\text { Lack of incentive from government to encourage emerging } \\
\text { contractors }{ }^{A}\end{array}$ \\
\hline 10 & Meeting contract deadlines ${ }^{\mathrm{A}}$ & Theft by employees ${ }^{\mathrm{C}}$ \\
\hline
\end{tabular}

${ }^{\dagger}$ Source: Adams (1997) [7].

${ }^{A}$ Constraints emanating for the business environment (external factors).

${ }^{\mathrm{B}}$ Constraints emanating from clients or client representations.

${ }^{\mathrm{C}}$ Constraints emanating from contractors' deficiencies.

\section{Appendix}

\section{Variables That Were Used in the Research for Malawian Small- and Medium-Scale Contractors (SMCs)}

(A) Variables to do with the business environment are as follows.

(1) Procuring work: scarcity of openly advertised tenders.

(2) Stringent conditions for small- and mediumscale contractors to access capital.

(3) Shortage of skilled labour.

(4) Uncertainty in supplies of materials.

(5) Uncertainty in prices of materials.

(6) Scarce work opportunities/unavailability of tenders for suitable work.

(7) Lack of detailed deliberate construction policy to develop indigenous contractors.

(8) Harsh/unrealistic demands to be fulfilled by small- or medium-scale contractors.

(9) Limited access to hire plant or equipment.

(10) Failure to meet contract deadlines by suppliers.

(11) Lack of communication with prospective clients.

(12) Failure to resolve contract disputes.

(13) Unavailability of vehicles to transport materials.

(14) Unavailability of vehicles to transport equipment to site.

(15) Failure to maintain plant or equipment.

(16) Inadequate institutional capacity in public sector or oversight organisations.
(17) High taxes.

(18) Double taxing.

(19) Ineffective training programmes for contractors.

(20) Inadequate training facilities for contractors.

(21) Corruption.

(22) Lack of ethics.

(23) Unfair competition (contract price undercutting by bigger contractors).

(24) Political interference.

(25) Forex shortages.

(26) Fuel shortages.

(27) Unavailability of credit lines from suppliers.

(28) Unavailability of credit lines from banks.

(29) Complicated registration procedure.

(30) Changes in government.

(31) Rapid changes in the economy.

(32) Prejudice against indigenous contractors' competence.

(33) Stringent requirements for obtaining bonds/ guarantees/sureties.

(34) Stringent requirements for obtaining insurance covers.

(35) Stringent requirements for obtaining letters of guarantee.

(36) Fluctuation of currency/exchange rate.

(37) Unstable government.

(38) Weak regulation of the construction industry.

(39) Weak technical control.

(40) Unpredictable weather conditions.

(41) Dependency on imported materials. 
(42) Risk and uncertainty associated with projects.

(43) Unstable interest rates.

(44) Lack of proper training on project management.

(45) Lack of proper experience of project management.

(46) Lack of appropriate software.

(47) Conflict between project parties.

(48) Disagreement in interpreting contract specifications.

(49) Low skilled manpower.

(50) Inflation of prices.

(51) High lending interest regimes for SMEs offered by financial institutions.

(52) Nepotism/racial discrimination.

(53) Lack of access to reliable information about contracts or tenders.

(54) Lack of incentive from government to encourage emerging contractors.

(55) Lack of professional advisors or consultants in the construction industry.

(56) Location of project.

(57) Green specifications (i.e., specifications of environmentally friendly materials).

(58) Use of energy efficient materials.

(59) Use of energy efficient plant or equipment.

(60) e-tendering (i.e., submission of tenders electronically).

(61) Environmental protection measures.

(B) Variables to do with client or client representative are as follows:

(1) Failure to pay interim certificates for contractors.

(2) Inappropriate contract conditions.

(3) Incomplete contract documents.

(4) Inadequate supervision by client.

(5) Design changes.

(6) Unsuitable standards or specifications.

(7) Unsuitable methods.

(8) Inadequate budget allocations.

(9) Failure to meet contract deadlines.

(10) Breach of contract by public clients.

(11) Inaccurate evaluation of projects time/duration.

(12) Nonperformance of nominated subcontractors or nominated suppliers.

(13) Discrepancies in contract documentation.

(14) Extensive use of competitive tendering in construction contracts.

(C) Variables to do with contractors' deficiencies are as follows:

(1) Failure to provide required quality of work.
(2) Lack of technical know-how.

(3) Deviations from plans.

(4) Deviations from specifications.

(5) Lack of communication on technical matters.

(6) Failure to provide reliable tenders.

(7) Failure to meet deadlines.

(8) Poorly prepared tenders or estimates.

(9) Poor accounting.

(10) Poor financial management.

(11) Poor planning of work.

(12) Poor planning of site.

(13) Failure to control materials on site.

(14) Poor company organisation.

(15) Poor personnel management.

(16) Poor public image.

(17) Lack of commitment to construction or abandoning site.

(18) Failure to provide collateral for securing financing.

(19) Budgetary overruns.

(20) Poor record keeping.

(21) Theft by employees.

(22) Fraud by employees.

(23) HIV/AIDS.

(24) Retrogressive cultural attitudes (e.g., prioritisation of petty cultural practice at the expense of productive undertakings).

(25) Retrogressive attitude towards democracy (e.g., deliberate misinterpretation of democratic and human rights).

(26) Retrogressive attitude towards gender (e.g., actions/policies that exclude members of opposite sex from participating in economic ventures).

(27) Retrogressive attitude towards funeral participation (e.g., exaggerating resources and time spent to attend to funerals).

(28) Complexity of works.

(29) Project fraud or corruption.

(30) Poor project planning.

(31) Project site management.

(32) Lack of ICT knowledge.

(33) Inability to develop long-term strategy.

(34) Inability to compete with bigger construction companies.

(35) Failure to provide safe working environment.

(36) Unmotivated employees.

(37) Huge absenteeism of workers on construction sites.

(38) Injuries on site.

(39) High labour turnover.

(40) Poor labour relations. 
(41) Poor contract management.

(42) Failure to negotiate variation order payment rates.

(43) Lack of business management skills.

\section{Conflict of Interests}

The authors declare that there is no conflict of interests regarding the publication of this paper.

\section{References}

[1] G. Sibanda, Creating an Enabling Environment for Small-Scale Contractors, Bulletin no. 9, International Labour Organisation/Advisory Support Information Services and Training for Labour-Based Programmes, Harare, Zimbabwe, 1999.

[2] National Construction Industry of Council (NCIC) of Malawi, "Construction firms classified by the national construction industry of council of Malawi," Annual Report, NCIC, Lilongwe, Malawi, 2010.

[3] C. M. Rogerson, "Road construction and small enterprise development: the experience of the N4 Maputo corridor," Development Southern Africa, vol. 17, no. 4, pp. 535-566, 2000.

[4] W. D. Thwala and M. Mvubu, "Current challenges and problems facing small and medium scale contractors in Swaziland," African Journal of Business Management, vol. 2, no. 5, pp. 9398, 2008.

[5] P. Bentall, A. Beusch, and J. Veen, Employment-Intensive Infrastructure Programmes: Capacity Building for Contracting in the Construction Sector Guidelines, ILO Publication, Geneva, Switzerland, 1999.

[6] R. L. Chilipunde, Constraints and challenges faced by small, medium and micro enterprise contractors in Malawi [M.S. thesis], Nelson Mandela Metropolitan University, Port Elizabeth, South Africa, 2010.

[7] O. Adams, "Contractor development in Nigeria: perceptions of contractors and professionals," Construction Management and Economics, vol. 15, no. 1, pp. 95-108, 1997.

[8] A. K. Eyiah, "An integrated approach to financing small contractors in developing countries: a conceptual model," Construction Management and Economics, vol. 19, no. 5, pp. 511-518, 2001.

[9] A. K. Eyiah and P. Cook, "Financing small and medium-scale contractors in developing countries: a Ghana case study," Construction Management and Economics, vol. 21, no. 4, pp. 357-367, 2003.

[10] Y. Frimpong, J. Oluwoye, and L. Crawford, "Causes of delay and cost overruns in construction of groundwater projects in a developing countries: Ghana as a case study," International Journal of Project Management, vol. 21, no. 5, pp. 321-326, 2003.

[11] J. Mbachu and R. Nkado, "Factors constraining successful building project implementation in South Africa," Construction Management and Economics, vol. 25, no. 1, pp. 39-54, 2007.

[12] C. Kaliba, M. Muya, and K. Mumba, "Cost escalation and schedule delays in road construction projects in Zambia," International Journal of Project Management, vol. 27, no. 5, pp. 522-531, 2009.

[13] O. I. Aje, K. T. Odusami, and D. R. Ogunsemi, "The impact of contractors' management capability on cost and time performance of construction projects in Nigeria," Journal of Financial Management of Property and Construction, vol. 14, no. 2, pp. 171$187,2009$.
[14] F. D. K. Fugar and A. B. Agyakwah-Baah, "Delays in building construction projects in Ghana," Australasian Journal of Construction Economics and Building, vol. 10, no. 1-2, pp. 103-116, 2010.

[15] S. O. Ogunlana, K. Promkuntong, and V. Jearkjirm, "Construction delays in a fast-growing economy: comparing Thailand with other economies," International Journal of Project Management, vol. 14, no. 1, pp. 37-45, 1996.

[16] M. Zakeri, P. O. Olomolaiye, G. D. Holt, and F. C. Harris, "A survey of constraints on Iranian construction operatives' productivity," Construction Management and Economics, vol. 14, no. 5, pp. 417-426, 1996.

[17] P. Kaming, P. Olomolaiye, G. Holt, and F. Harris, "Factors influencing construction time and cost overruns on highrise projects in Indonesia," Construction Management and Economics, vol. 15, no. 1, pp. 83-94, 1997.

[18] A. M. Odeh and H. T. Battaineh, "Causes of construction delay: traditional contracts," International Journal of Project Management, vol. 20, no. 1, pp. 67-73, 2002.

[19] K. C. Iyer and K. N. Jha, "Factors affecting cost performance: evidence from Indian construction projects," International Journal of Project Management, vol. 23, no. 4, pp. 283-295, 2005.

[20] P. A. Koushki, K. Al-Rashid, and N. Kartam, "Delays and cost increases in the construction of private residential projects in Kuwait," Construction Management and Economics, vol. 23, no. 3, pp. 285-294, 2005.

[21] S. A. Assaf and S. Al-Hejji, "Causes of delay in large construction projects," International Journal of Project Management, vol. 24, no. 4, pp. 349-357, 2006.

[22] W. Alaghbari, M. R. A. Kadir, and A. Salim, "The significant factors causing delay of building construction projects in Malaysia," Engineering, Construction and Architectural Management, vol. 14, no. 2, pp. 192-206, 2007.

[23] G. Sweis, R. Sweis, A. Abu Hammad, and A. Shboul, "Delays in construction projects: the case of Jordan," International Journal of Project Management, vol. 26, no. 6, pp. 665-674, 2008.

[24] J.-K. Lee, "Cost overrun and cause in Korean social overhead capital projects: roads, rails, airports, and ports," Journal of Urban Planning and Development, vol. 134, no. 2, pp. 59-62, 2008.

[25] A. Al-Kharashi and M. Skitmore, "Causes of delays in Saudi Arabia public sector construction projects," International Journal of Project Management, vol. 27, no. 1, pp. 3-23, 2009.

[26] A. Enshassi, J. Al-Najjar, and M. Kumaraswamy, "Delays and cost overruns in the construction projects in the Gaza strip," Journal of Financial Management of Property and Construction, vol. 14, no. 2, pp. 126-151, 2009.

[27] B.-G. Hwang, X. Zhao, and S. Y. Ng, "Identifying the critical factors affecting schedule performance of public housing projects," Habitat International, vol. 38, pp. 214-221, 2013.

[28] P. P. Shrestha, L. A. Burns, and D. R. Shields, "Magnitude of construction cost and schedule overruns in public work projects," Journal of Construction Engineering, vol. 2013, Article ID 935978, 9 pages, 2013.

[29] A. M. Jarkas and J. H. Younes, "Principle factors contributing to construction delays in the State of Qatar," International Journal of Construction Project Management, vol. 6, no. 1, pp. 39-62, 2014.

[30] P. James, "Managerial challenges impacting on a TBM design: a Kingdom of Saudi Arabia metro project," Engineering Management Research, vol. 3, no. 2, pp. 32-46, 2014. 
[31] Y. A. Olawale and M. Sun, "Cost and time control of construction projects: Inhibiting factors and mitigating measures in practice," Construction Management and Economics, vol. 28, no. 5, pp. 509-526, 2010.

[32] M. H. Fallahnejad, "Delay causes in Iran gas pipeline projects," International Journal of Project Management, vol. 31, no. 1, pp. 136-146, 2013.

[33] G. Ofori, "Programmes for improving the performance of contracting firms in developing countries: a review of approaches and appropriate options," Construction Management and Economics, vol. 9, no. 1, pp. 19-38, 2006.

[34] A. P. C. Chan and A. P. L. Chan, "Key performance indicators for measuring construction success," Benchmarking, vol. 11, no. 2, pp. 203-221, 2004.

[35] G. Kululanga, "Capacity building of construction industries in Sub-Saharan developing countries: a case for Malawi," Engineering, Construction and Architectural Management, vol. 19, no. 1, pp. 86-100, 2012.

[36] D. W. M. Chan and M. M. Kumaraswamy, "A comparative study of causes of time overruns in Hong Kong construction projects," International Journal of Project Management, vol. 15, no. 1, pp. 55-63, 1997.

[37] T. M. S. Elhag, A. H. Boussabaine, and T. M. A. Ballal, "Critical determinants of construction tendering costs: quantity surveyors' standpoint," International Journal of Project Management, vol. 23, no. 7, pp. 538-545, 2005.

[38] D. C. Okpala and A. N. Aniekwu, "Causes of high costs of construction in Nigeria," Journal of Construction Engineering and Management, vol. 114, no. 2, pp. 233-244, 1988.

[39] C. Navarre and J. L. Schaan, "Design of project management systems from top management's perspective," Project Management Journal, vol. 21, no. 2, pp. 19-27, 1990.

[40] R. Atkinson, "Project management: cost, time and quality, two best guesses and a phenomenon, its time to accept other success criteria," International Journal of Project Management, vol. 17, no. 6, pp. 337-342, 1999.

[41] R. N. Nkado, "Construction time-influencing factors: the contractor's perspective," Construction Management and Economics, vol. 13, no. 1, pp. 81-89, 1995.

[42] S. M. Latham, Constructing the Team: Final Report of the Government/Industry Review of Procurement and Contractual Arrangements in the UK Construction Industry, HMSO, London, UK, 1994.

[43] Project Management Institute Inc, Construction Extension to the $P M B O K$, Project Management Institute Inc, Newtown Square, Pa, USA, 3rd edition, 2007.

[44] G. Fernández-Sánchez and F. Rodríguez-López, "A methodology to identify sustainability indicators in construction project management-application to infrastructure projects in Spain," Ecological Indicators, vol. 10, no. 6, pp. 1193-1201, 2010.

[45] C. Soanes and A. Stevenson, Concise Oxford English Dictionary, Oxford University Press, Oxford, UK, 11th edition, 2008.

[46] A. Griffin, Small Building Works Management, The Macmillan Press, London, UK, 1992.

[47] J. Oakland and M. Marosszeky, Total Quality in the Construction Supply Chain, Butterworth-Heinemann, London, UK, 2006.

[48] D. Arditi, G. T. Akan, and S. Gurdamar, "Cost overruns in public projects," International Journal of Project Management, vol. 3, no. 4, pp. 218-224, 1985.

[49] T. M. Mezher and W. Tawil, "Causes of delays in the construction industry in Lebanon," Engineering Construction and Architectural Management, vol. 5, no. 3, pp. 252-260, 1998.
[50] T. Y. Lo, I. W. H. Fung, and K. C. F. Tung, "Construction delays in Hong Kong civil engineering projects," Journal of Construction Engineering and Management, vol. 132, no. 6, pp. 636-649, 2006.

[51] H. Abdul-Rahman, M. A. Berawi, A. R. Berawi, O. Mohamed, M. Othman, and I. A. Yahya, "Delay mitigation in the Malaysian construction industry," Journal of Construction Engineering and Management, vol. 132, no. 2, pp. 125-133, 2006.

[52] K. Lysons and B. Farrington, Purchasing and Supply Chain Management, Prentice Hall, London, UK, 7th edition, 2006.

[53] S. Laryea, "Quality of tender documents: case studies from the UK," Construction Management and Economics, vol. 29, no. 3, pp. 275-286, 2011.

[54] B. Cooke and P. Williams, Construction Planning Programming and Control, Macmillan Press, London, UK, 1998.

[55] W. J. O’Brien, C. T. Formoso, R. Vrijhoef, and K. A. London, Construction Supply Chain Management Handbook, CRC Press, London, UK, 2009.

[56] P. G. Ioannou and R. E. Awwad, "Below-average bidding method," Journal of Construction Engineering and Management, vol. 136, no. 9, pp. 936-946, 2010.

[57] F. Harris, R. McCaffer, and F. Edum-Fotwe, Modern Construction Management, Wiley-Blackwell, New York, NY, USA, 7th edition, 2013.

[58] R. J. Mayer, M. K. Painter, and M. Lingineni, Information Integration for Concurrent Engineering (IICE) Towards a Method for Business Constraint Discovery (IDEF9), Human Resources Directorate Logistics Research Division, Knowledge Based Systems, College Station, Tex, USA, 1995.

[59] M. Whelton, A. Penneanen, and G. Ballard, "Knowledge emergence and adaptive management: an exploration on the coproduction of project needs and requirements by client-Specialist groups," in Knowledge Management in the Construction Industry: A Socio-Technical Perspective, A. S. Kazi, Ed., pp. 251275, Idea Group Publishing, Hershey, Pa, USA, 2004.

[60] E. M. Goldratt, Theory of Constraints, North River Press, Croton-On-Hudson, NY, USA, 1990.

[61] D. K. H. Chua, L. J. Shen, and S. H. Bok, "Constralnt-based planning with integrated production scheduler over internet," Journal of Construction Engineering and Management, vol. 129, no. 3, pp. 293-301, 2003.

[62] N. R. Mansfield, O. O. Ugwu, and T. Doran, "Causes of delay and cost overruns in Nigerian construction projects," International Journal of Project Management, vol. 12, no. 4, pp. 254-260, 1994.

[63] A. A. Aibinu and G. O. Jagboro, "The effects of construction delays on project delivery in Nigerian construction industry," International Journal of Project Management, vol. 20, no. 8, pp. 593-599, 2002.

[64] M. M Dlakwa and M. F Culpin, "Reasons for overrun in public sector construction projects in Nigeria," International Journal of Project Management, vol. 8, no. 4, pp. 237-241, 1990.

[65] A. U. Elinwa and M. Joshua, "Time-overrun factors in Nigerian construction industry," Journal of Construction Engineering and Management, vol. 127, no. 5, pp. 419-425, 2001.

[66] P. Bowen, A. Akintoye, R. Pearl, and P. J. Edwards, "Ethical behaviour in the South African construction industry," Construction Management and Economics, vol. 25, no. 6, pp. 631648, 2007.

[67] P. A. Bowen, P. J. Edwards, and K. Cattell, "Corruption in the South African construction industry: a thematic analysis of verbatim comments from survey participants," Construction Management and Economics, vol. 30, no. 10, pp. 885-901, 2012. 
[68] M. Saunders, P. Lewis, and A. Thornhill, Research Methods for Business Students, Pearson Education, Essex, UK, 5th edition, 2009.

[69] A. Bryman, Social Research Methods, Oxford University Press, New York, NY, USA, 3rd edition, 2008.

[70] O. A. Akintan and R. Morledge, "Improving the collaboration between main contractors and subcontractors within traditional construction procurement," Journal of Construction Engineering, vol. 2013, Article ID 281236, 11 pages, 2013.

[71] J. G. Bartlett II, J. W. Kotrlik, and C. C. Higgins, "Organizational research: determining appropriate sample size in survey research," Information Technology, Learning and Performance Journal, vol. 19, no. 1, pp. 43-50, 2001.

[72] National Construction Industry of Council (NCIC) of Malawi, "Construction firms registered by the National Construction Industry of Council of Malawi," Annual Report, NCIC, Lilongwe, Malawi, 2012.

[73] P. D. Leedy and J. E. Ormond, Practical Research Planning and Design, Prentice-Hall, Upper Saddle River, NJ, USA, 2005.

[74] A. Field, Discovering Statistics Using IMB SPSS Statistics, Sage Publications, London, UK, 4th edition, 2013.

[75] A. Clarke, "A practical use of key success factors to improve the effectiveness of project management," International Journal of Project Management, vol. 17, no. 3, pp. 139-145, 1999.

[76] K. Richard, The 80/20 Principle: The Secret to Achieving More with Less, Doubleday Publishing Group, New York, NY, USA, 1999.

[77] A. C. Tahir and R. C. Darton, "The process analysis method of selecting indicators to quantify the sustainability performance of a business operation," Journal of Cleaner Production, vol. 18, no. 16-17, pp. 1598-1607, 2010. 

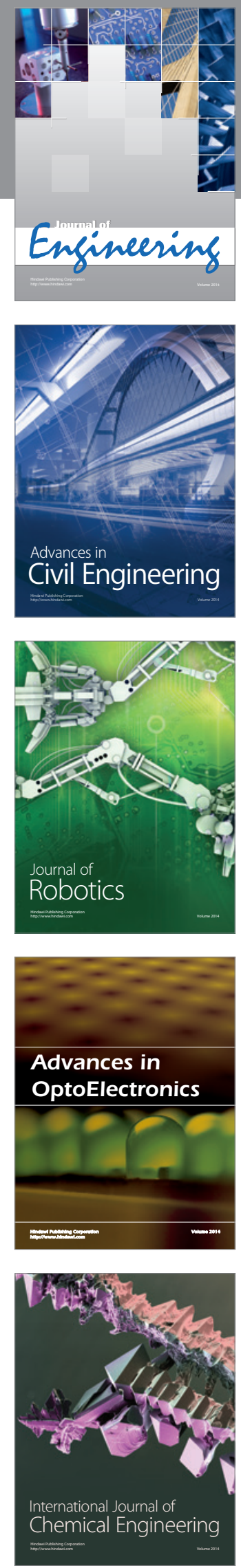

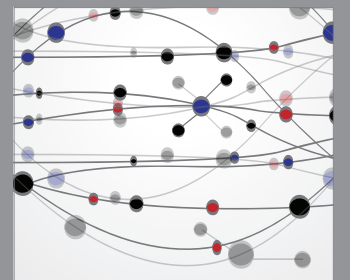

The Scientific World Journal
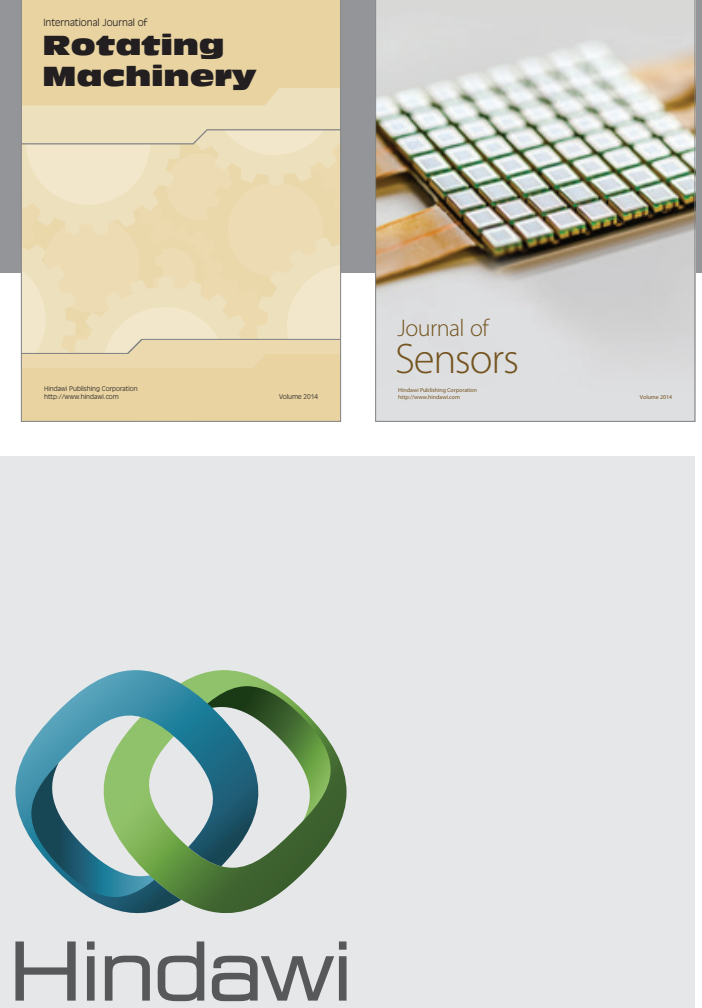

Submit your manuscripts at http://www.hindawi.com
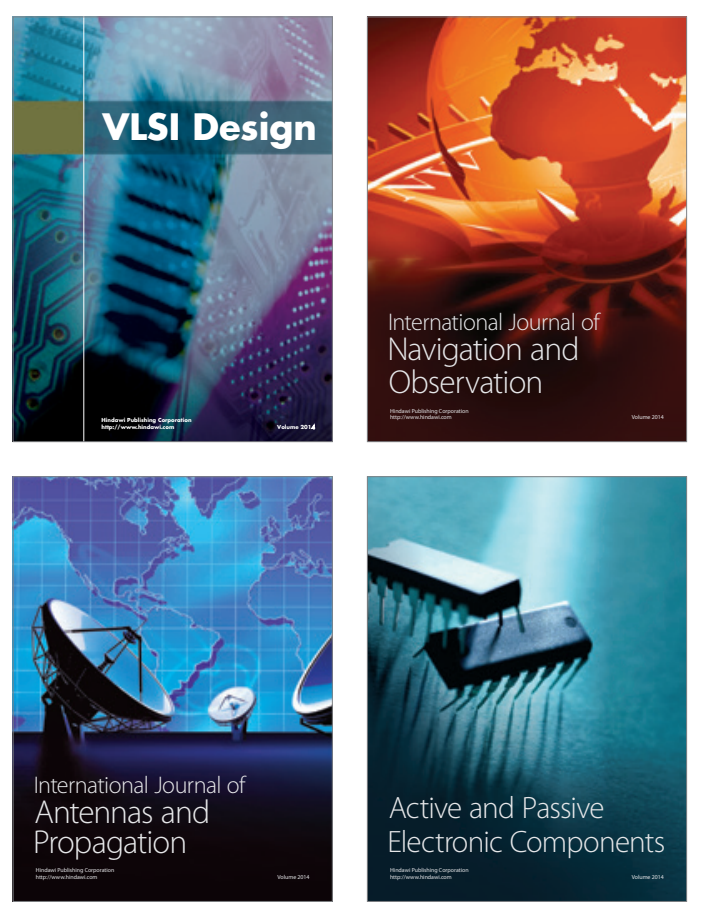
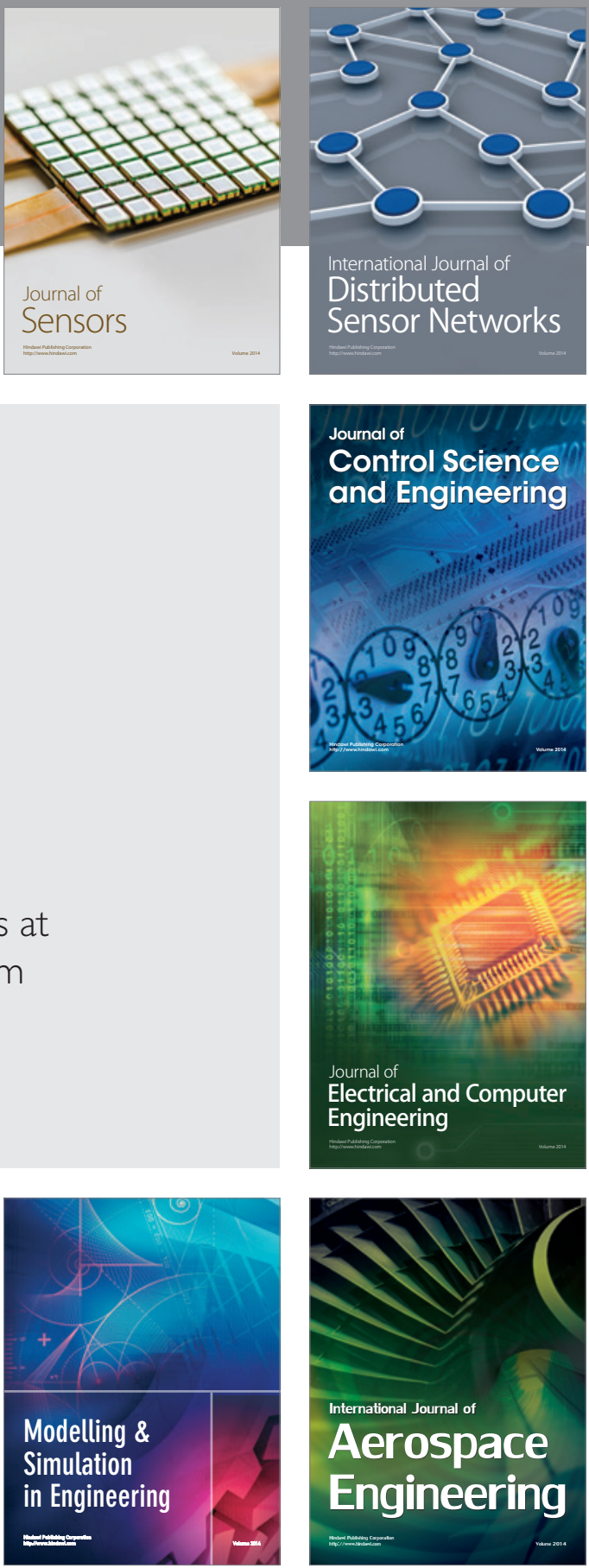

Journal of

Control Science

and Engineering
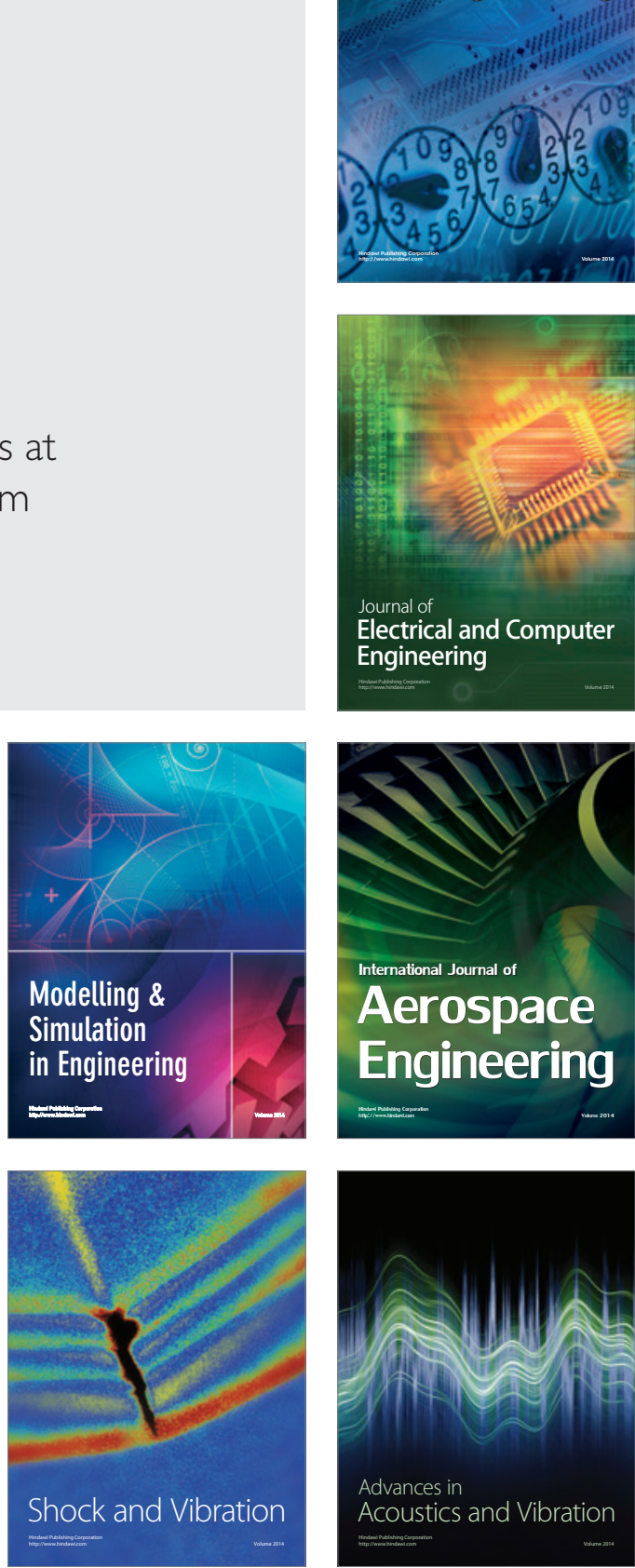